\title{
Mentorship and Induction: \\ Negotiating a Collaborative Enterprise or \\ Apprenticing for Status Quo Maintenance?
}

\author{
Christine L. Cho \\ York University
}

Sarah Elizabeth Barrett

York University

R. Patrick Solomon

York University

John P. Portelli

OISE/University of Toronto

Donatille Mujawamariya

University of Ottawa

Christine Cho is doctoral candidate (ABD) at York University's Faculty of Education and the Community Involvement Co-ordinator for the York Urban Diversity B.Ed. programme. A classroom teacher for several years, Christine has taught pre-service and in-service teachers at four Ontario universities. Her research interests include the exploration of social justice in pre-service teacher education particularly related to "immigrant" teacher candidates, teacher education policy and practices, critical pedagogy, and critical multiculturalism.

Sarah Elizabeth Barrett, PhD., is an assistant professor at York University's Faculty of Education, where she teaches Cultural Studies in Science Education and Foundations of Education. Her research interests include teacher education, inclusive curriculum and teaching science for social justice.

R. Patrick Solomon, PhD., was a professor at York University's Faculty of Education, where he taught Foundations of Education in the Urban Diversity program he co-founded. His research interests included teacher preparation for the urban environment and racialized minorities' access to teacher education and teaching. Dr. Solomon passed away in October 2008.

Donatille Mujawamariya, Ph. D., is an associate professor at the University of Ottawa in the Faculty of Education. Her teaching and research interests include: Science teaching, teacher education, multicultural and antiracist education as well as questions concerning inequalities in general.

John P. Portelli is a Professor and Associate Chair of the Department of Theory and Policy Studies, and Co-director of the Centre for Leadership and Diversity at OISE/UT. He teaches in the History and Philosophy of Education Program and the Educational Administration Program. His major research interest is in democratic values, leadership and policy in education.

Brock Education, Volume 18, No. 2, Spring 2009, 114-130 


\title{
Mentorship and Induction: Negotiating a Collaborative Enterprise or Apprenticing for Status Quo Maintenance?
}

\begin{abstract}
This paper is from a three-year research project that examined the Ontario (Canada) government philosophy, policy and practice in moving from standardized teacher testing to a new teacher induction program (NTIP) to achieve teacher quality and competence. This paper utilizes a critical democratic perspective to analyze the perspectives of 47 teacher educators from 10 faculties of education in Ontario. Two major themes arose from their perspectives on NTIP: a) clear collaboration/partnership among stakeholders (including faculty, school boards, schools, communities); and, b) increasing effective communication and knowledge while maintaining the importance of equity, diversity and understanding community. The findings revealed the need for a more critical examination of the process and outcome of mentorship and induction programs for new teachers.
\end{abstract}

The objective of this paper is to extend the research around mentorship and to critique new teacher induction programs as a pedagogical approach to the government rhetoric of measurable accountability. We believe that the increasingly standardized teaching environment in Ontario and North America has given rise to a climate of conformity. While some teacher educators may be satisfied with their preparation of future teachers for the so-called realities of the classroom, others are concerned with ways to disrupt the reproductive aspects of schooling and striving to prepare future teachers to be agents of change (Giroux, 1988). In our analysis, we draw from critical-democratic teacher education (Darling-Hammond, 1998), as a perspective that values divergent and dialogical inquiry, open-mindedness, critical abilities and questioning, equity and taking alternatives seriously (Portelli \& Solomon, 2001). We take the position that there is an intrinsic connection between education and democracy and that centralization of policy making and politicized accountability measures (Apple, 2006) are at odds with pedagogic practices that encourage open discourses about equity and social justice. We are interested in understanding teacher educators' underlying philosophy of the NTIP program and the implications for the effect of teacher induction and mentoring programs on classroom teaching.

In the fall of 2006, the Ontario Ministry of Education introduced a new initiative, the New Teacher Induction Program (NTIP) designed to support the growth and professional development of new teachers in Ontario's publicly funded schools (Ontario Ministry of Education, 2006b). Touted as the second step in a professional development continuum it is designed to complement the first step: pre-service education programs. The initiative strives to "provide another full year of professional support so that new teachers can develop the requisite skills and knowledge that will enable them to achieve success as experienced teachers in Ontario" (Ontario Ministry of Education, 2006a). This new initiative replaces the Ontario Teacher Qualifying Test (OTQT), a pencil and paper test implemented for the first time in 2004 with the express intention of standardizing teachers in Ontario. NTIP focuses on teacher professionalism tied to quality assurance and public accountability - not unlike the 
purported focus of the OTQT. The stated aims of NTIP include development and training in the following areas: Literacy and Numeracy strategies; Student Success; Safe Schools; and Politique d'aménagement linguistique in French-language boards; classroom management; effective parent communication skills; and instructional strategies that address the learning and culture of students with special needs and other diverse learners (Ontario Ministry of Education, 2006a). Thus, the elements of NTIP are closely aligned with current Ontario Ministry policies with the specific stated goal of creating "better prepared and more confident teachers" (Ontario Ministry of Education, 2006a). Proportional funding based on the number of new teachers in relationship to the rest of the province is allocated to each school board for schoolbased induction resources and activities. The public and many teachers embraced NTIP as the best alternative to the OTQT with little reservation regarding the underlying philosophy of its implementation.

This paper is part of a larger study that examines NTIP from the standpoint of new teachers, school administrators and teacher educators. We are interested in the perspectives of teacher educators who are directly involved in what the Ministry deems the first step of teacher education: the pre-service program. Specifically, we explore their insights on teacher induction and mentorship. Central to our theoretical framework is an understanding that education is full of contradictions. We recognize that knowledge is neither neutral nor objective, but, is a social construction rooted in a nexus of power relations (McLaren, 2003). Drawing from Kincheloe and McLaren (1998) we seek to raise questions about unexamined, daily practices and to tease apart the social political implications embedded within the taken-for-granted (Simon, 1992).We consider those future teacher educators who might benefit from an induction and mentorship program and those who may be further disadvantaged by an already inequitable system (Foster, 1990). Our research questions, therefore, are the following: Does mentorship entail collaboration? With whom? For what purposes? Will induction favour socially just education that values the principles of equity and diversity or will induction serve to further reproduce the inequities in society within our schools?

\section{Literature Review}

Despite multiracial, multiethnic, multilingual and varied socio-economic status representation of students in our schools, the norm in Canadian schools is a white, middle-class homogenous representation amongst teaching staff (Bascia, 1996). Schools consciously and unconsciously contribute to the maintenance of this status quo by reproducing and maintaining existing power imbalances (Giroux, 1983). Indeed, the process of becoming a teacher involves many facets of cultural reproduction including the socializing of pre-service teachers into the profession (Britzman, 1986). The socialization of teachers begins through schooling and the apprenticeship of observation (Lortie, 1975) continues in the faculty of education and is taken up in earnest during practicum placements. There exists a tension between what is seen as good practice in the faculties of education and the reality of teaching in the classroom (Hargreaves, 1995). New teachers often discover, as they leave faculties of education, that their understandings of what it means to be a teacher is in conflict with the reality they discover in schools (Flores, 2007). Too often, new teacher identity and visions of 
socially-just teaching practices are challenged by the experienced teachers they encounter. As such, the first year of teaching may be a time to solidify the socialization begun in the faculties of education or it may be a time to pre-empt it. Wang and Odell (2002) argue that mentoring programs arise from a) a perceived need to standardize the teaching profession and b) to counter what many classroom teachers view as the ineffectiveness of teacher education programs. There is an assumption, echoed in the policy reforms, that standardization will make for better teachers which in turn will ensure student success. Embedded in the concept of mentorship is the notion that mentoring is practice-based rather than theory-based, is done in the field and is conducted at the practicum school as opposed to the university. Theoretical knowledge then becomes fragmented from the everyday reality of teaching (Britzman, 2003). Indeed, much of what is explored in the literature is using mentoring and induction to provide ways for new teachers to enter the profession smoothly (see Villani, 2002 for notable examples). This smoothness implies implicit acceptance of the current system and explicit efforts to fit into that system. Thus, information about the school system is acquired; it is not critiqued.

Induction programs have been advocated by many as a way to convey essential knowledge to new teachers in different contexts (Cho \& Kwon, 2004; Kennedy \& Burnstein, 2004). Mentorship connotes images of a more knowledgeable individual assigned or perhaps selected by a novice to gain deeper understanding of the teaching profession. Mentorship and induction can be viewed as either an apprenticeship model which suggests assimilation into a profession or a collaborative model which stresses the exchange of ideas.

When mentorship is constructed though an apprenticeship model, the focus is on the mentor as technical support (see Wang and Odell, 2002) for a full discussion of the situated apprentice perspective). In an apprenticeship model, efficient assimilation into the existing notions of what it means to be a teacher and maintaining the status quo is paramount. The apprenticeship approach to mentoring has been criticized for reproducing the status quo through its focus on the practical aspects of teaching, for narrowing the perspective on teacher education (Zeichner \& Gore, 1990) and for not examining what novice teachers need to know (Cochran-Smith \& Paris, 1995).

Conversely, mentorship can be viewed as collaborative work in which the learning process is reciprocal. Both the seasoned mentor and the novice mentee are negotiating new knowledge (Cochran-Smith \& Lytle, 1999). A collaborative model strives to balance the particular and individual needs of the novice teacher with larger societal issues (Jones, 2006). The focus here is on risk-taking and growth and on furthering the process of individual teacher identity presumably begun in the faculties of education. Collaborative work also offers opportunities for the seasoned mentor to explore and benefit from new theoretical approaches to teaching.

\section{Methods of Inquiry and Data Sources}

This tri-university study, involving researchers from the OISE/University of Toronto; York University and the University of Ottawa, utilized both qualitative and quantitative research methodologies, combining the use of open-ended surveys and in-depth, semistructured interviews (Creswell, 1998; Tashakkori \& Teddlie, 1998). In-depth interviews 
were conducted with 132 participants, 47 of whom were teacher educators (TEs). The teacher educators were selected from both French and English faculties for maximum variation in subject specialization, institution, gender, culture, ethnic background and geographical region. Interviews mainly focused on: what specific skills and knowledge mentoring/induction programs should address to prepare new teachers for the contemporary multi-racial, multi-cultural, and multi-class Ontario context; how the programs should be administered and assessed; and who could make a good mentor. In addition, we prompted all participants to discuss the role of equity and diversity as they related to mentoring and induction (see Appendix A for a sample of questions posed and prompts used). The TEs represent 10 faculties of education in Ontario, Canada and consisted of 17 males and 30 females; 42 were in English faculties and 5 were in French faculties. Interviews were recorded and described. The data were analyzed inductively, using the techniques described by Bogdan and Biklen (1998). Analysis of the data included process coding. The codes reflected the common and various themes that emerged from the data. It should be noted that the qualitative data analysis occurred simultaneously with data collection. The data were analyzed using what Tesch (1990) characterized as "de-contextualization" in order to identify themes and coding categories and "re-contextualization" to present a unified and coherent picture. The research team reduced the data to reveal emerging themes that reflected the respondent's perspectives/practices and to provide directionality. The research team worked in pairs to develop the data reductions with each member of each pair reviewing their partner's analysis. Given the number of participants, member-checking was not possible; however, emerging themes were brought to the whole research team for further analysis. Finally, another researcher, who had not been part of the original research team, reviewed all of the data, checking for bias in the reductions by returning to the original transcripts and checking to see if she agreed with the research teams' themes.

\section{Findings and Discussion}

While several themes were identified in the research, we will focus on two in this paper: clear collaboration/partnership among stakeholders (including faculty, school boards, schools, communities) and; increasing effective communication and knowledge while maintaining the importance of equity, diversity and understanding community. These two themes were reflective of significant tensions within the data.

\section{Clear Collaboration/Partnership Among Stakeholders.}

NTIP is reportedly designed to compliment pre-service education (Ontario Ministry of Education, 2006a). The interviewed TEs, however, seemed unaware of the mentorship/induction program which was apparently implemented without faculty of education input. Teacher educators in Ontario faculties are mainly drawn from three groups: contract instructors; seconded school teachers and administrators; permanent faculty. Secondees are typically teacher educators seconded from the field for a contract term of two to three years. These individuals may be principals, consultants, and/or classroom teachers. In most cases, seconded faculty has 100 percent teaching responsibilities, though they may be involved in research at the faculties. Contract 
instructors are from various backgrounds, including graduate students and retired teachers who teach on a per course basis. Their teaching loads vary and they may or may not be involved in research. Permanent faculty has research as well as teaching and service responsibilities. Seconded, contract and permanent faculty were interviewed and perhaps not surprisingly the groups often had differing views with respect to collaboration and potential partnership opportunities that might arise with NTIP. While respondents strongly supported establishing clear collaboration and partnerships among stakeholders, opinions about the optimum structure of the partnership and the collaborative role differed amongst TEs. Most TEs felt the local school boards should not be solely responsible for the induction program, although most felt the local school board was the most appropriate stakeholder to oversee NTIP. Ideally, TEs felt that the theorybased faculty should offer assistance when the practice-based school board is in need. This would require focus on the exchange and flow of information and resources between faculties and school boards. In general sentiment reflected a more collaborative approach to mentorship for overall success.

I like the idea of teacher educators being involved in the induction, because, it's not [suggesting] "we have done our part now you go do yours", because, there's always this big argument between the boards and the faculties saying [TEs] don't prepare our teachers, [the boards approach education] from the very traditional mode of thinking, teaching training. [Amina]

The respondents' concern regarding collaboration amongst stakeholders illuminates a deeper tension in the faculties of education themselves: faculty who are research-based as opposed to those who are primarily instruction-based. Those with stronger connections to the boards of education (such as seconded teachers and retired principals) may have closer alliances and allegiances with Ministry policies and may be less likely to press for any perceived interference by the faculties of education. Some faculty may be more skeptical of school board involvement without universities/faculties of education actively involved in the mentoring and induction process. Knowing the government's policies and keeping current with the rhetoric, for example, seems to take precedence over teacher praxis for some teacher educators. Specific initiatives such as those in the areas of literacy and numeracy were cited as examples in which there are curriculum leaders in the schools who have the responsibility of disseminating information and modeling Ministry best practices for classroom teachers. Some faculty respondents indicated new teachers need broader knowledge of legislation to ensure teacher autonomy and to be able to interrogate and critique policy.

Both the theoretical and the practical aspects that are in teacher education must also be in the teacher induction program.... One of the reasons why we have had such a difficult time retaining teachers is precisely, because, teachers....[are] being asked to not think. They've been asked to just follow the recipe of the provincial curriculum. And that's essentially a very unsatisfying way of working. [Heather]

In contrast, the following respondent, a contract instructor feels strongly that the mentor should be a practicing teacher precisely, because, s/he would more likely be aligned with governmental policies:

You don't want someone who's been out of the field who doesn't know some of the new policies, some of the new changes that have been going on. [Anne] 
While the suggestion of partnerships seems to be lauded by most, the way in which this collaboration could be created or further enhanced was not agreed upon. Retired teachers, for example and principals were seen as both ideal mentors by many respondents while others indicated these stakeholders should not be involved in a mentorship role. For instance, one respondent, who was asked "who would make an ideal mentor", replied,

It's the kind of person, often, that we get who comes back as adjuncts after they've retired. You can see how conscientious they are. You just notice them around the building doing their preparations and so on. They may only have classes for, say, two hours a week or something like that, but, they're around the building much more than that. You need somebody who's really dedicated. [Harry]

In contrast, this participant offers the following:

I'm concerned about administrators.... being appropriate mentors....given the certain things that they have to do. Would they become more of an institutional mentor as opposed to a more intellectual and professional mentor? [Haniff]

Here, the respondent is concerned with the tension between status quo maintenance and challenging the existing system. The prioritization of theory over practice or vice versa is contentious and is epitomized as tension among different TEs. This element is evidenced by one respondent:

So unless teacher educators are part of that induction program, I don't think there will be anybody out there who wants to touch theory looking at the sociology and looking at the politics and looking at the history of education. So that's why I'm a little skeptical about how an induction program would include all of this if there aren't teacher educators out there pushing for this. [Aiesha]

This quote is particularly interesting, because, it is from a secondee and suggests that classroom teachers and administrators would not be stressing aspects of social justice in the schools, but, rather it is incumbent upon teacher educators to do this work. The tension between the practical-based schools and the theory-based University is summed up by this respondent:

One thing the administrators said was that teacher education faculties know nothing about what's going on in the schools... this criticism is half true. It results from the fact that faculties and school teachers are differently positioned, and these very stances or positionalities....can contribute to more collaboration and connections between school community and education. [Peter]

This respondent also suggests that,

It's equally troubling for a faculty to say that teachers and administrators are so lost in their own climate of the school that they are reproducing these inequitable structures and producing, not engaging in critical thinking. [Peter]

Respondents also suggests exploring the ways in which other professions ease novices into practice, such as articling for law students or residency programs for doctors. Lave and Wenger's (1999) concept of communities of practice was raised by other TEs. This approach was thoroughly explored thoroughly by one respondent:

Clearly what the government needs to do is to establish mentors and mentorship where existing in-service teachers would continue to take courses for advance coursework, where they would be exposed to adult learning models, where they would be exposed to graduate programs, where they could enhance their role and get some sort of official recognition, where they can then train the eyes and ears of 
new inductees and novices in terms of bringing what they're learning in their preservice program into the context of the classroom. [Haniff]

This collaborative approach stresses the idea of reciprocity that Cochran-Smith and Lytle (1999) espouse. A collaborative model involves the exchange of information and new learnings and also invites a critical examination of the education system. Indeed, this respondent was also concerned with balancing necessary knowledge with critical interpretation of student expectations and of curriculum outcomes.

Most respondents favour a collaborative program based on commitment to and encouragement of a strong relationship between faculties of education and schools. Most contract and seconded faculty suggested the possibility of Ministry of Education involvement and some suggested involvement of the school unions (Federations).

\section{Increasing Effective Communication and Knowledge While Maintaining the Importance of Equity, Diversity and Understanding Community}

The socialization of new teachers into the schooling process (Britzman, 1986) was voiced by a few participants. Jones (2006) identified the individual needs of the novice teacher to align with larger societal issues. Some respondants were critically aware of the need for new teachers to partner with a mentor who could navigate the school community and infuse notions of social justice as part of their teaching practice. Others were concerned that such partnership would serve to reinforce the status quo, and would thus maintain existing power imbalances (Giroux, 1983). Those who envision mentorship believe that transformative teaching practice should begin in the faculty where the mentees can learn why it is important to develop competencies for working on equity issues... As one respondent noted,

I think that there's just too much of this hands-on practical stuff that is pushed forward and not the thinking part. The inquiry is being lost and then we wonder why teachers are technocrats. . .[New teachers] are more concerned about how your classroom looks, not to say that that isn't relevant to a certain extent, but, why are you teaching what you are teaching? What is the basis for your programming? Think deeper and broader. What is it about the curriculum that seems to be so static? [Aiesha]

This respondent's critical approach to mentorship asks new teachers to look for areas of improvement within schools. This position that may be threatening to seasoned teachers who may have grown accustomed to the status quo and who are not necessarily looking critically at the structure of schools. As this permanent faculty member comments:

The whole notion of pedagogy should play an important role. ... I think that some of the foundational issues should be an ongoing dialogue with the students from teacher's college, because, to be honest with you around issues of diversity, I'm not trusting the school boards very much. [Nalini]

Nalini is concerned that induction in the school board will not address issues of equity or diversity, but, would rather, for example, focus on classroom management. This is an aspect of teaching she thinks is overly emphasized in the schools. As another participant comments,

I just think that if we keep picking host teachers the way we do we are undoing a lot of what we are trying to do in the Faculty. And I don't think teacher candidates 
have strong enough foundations to go into schools and recognize what's not appropriate and challenge anybody on it, but, we can't ask them to do that when they are brand new pre-service candidates. [Brenda]

Mentors may view their role as one who transitions a new teacher into the profession, one who assists with classroom management, one who allocates resources, and other socalled professional tasks (Villani, 2002). The stance of addressing the high priority needs of new teachers is supported by the stated objectives and elements of many induction programs. Conversely, as the above respondent suggests, if the mentor's role is seen as collaborative, they may be in an ideal position to: work as Cochran-Smith and Lytle (1999) suggest, as change agents with new teachers; to explore what a fresh set of eyes sees within the school system and; to examine the ways in which the existing system fails some of our students.

While universities and school boards may have differing ideas as to what new teachers need to know in order to successfully transition into teaching, not all knowledge is necessarily viewed equally or equally validated. Such sentiment is epitomized by this respondent:

I think I have to return to what kind of skills, knowledge and dispositions we want them to exit with. For example, we have to balance getting them familiar with the curriculum, but, also being able to interpret the curriculum for its strengths and weaknesses. [Haniff]

This critical approach is also echoed in this next quote. The respondant criticizes how teachers are prepared to teach with socially just, equitable and diverse ways:

Issues of diversity ...should be an important issue...It's not only the transference of the basic subjects that the students have to learn. [Nalini]

Embedded within the stated outcomes of induction programs is a taken-for-granted assumption that there exists a common understanding of what skills and training new teachers require to be successful. In Ontario, for example, one of the stated intentions of NTIP is alignment with the government's initiatives. For many respondents becoming a teacher is much more than alignment with the current government's agenda. Rather, they look more universally at preparing teachers for numerous contexts, situations and environments:

I want to have math teachers who teach very well and can transfer that kind of knowledge, but, at the same time to look at the diversity of the students in terms of gender, race, sexuality and other things. [Nalini]

This TE and others hold a perspective that teaching should transcend governmental policies.

In this research, several TEs had issues with the Faculty itself. The respondents criticized their own programs for not representing the principles of equity and diversity they advocate, for a lack of critical sense, for their detachment from the field, and for not preparing future teachers to deal effectively with academically disadvantaged students. These criticisms are in stark contrast to the so-called idealistic vision often levied against faculties of education by classroom teachers (Britzman, 2003). That is, embedded within the philosophies of many of our faculties of education is the very notion that social justice and socially-minded education takes precedence over teaching the fundamentals of reading, writing and mathematics. 
I think that learning to deal with learner difference is something that almost nobody would dispute, but, the actual articulation of the vision of what that difference constitutes as a challenge in your teaching, is not there.... The fleshing out is missing, a lack of courage to take an explicit social justice perspective on them. You know, we can say that [this university] stands for social justice and everything it does, but, there's no institutional resourcing, there's no democratic mechanism for faculty to have to debate out what their responsibilities are going to be, there's no explicit rewarding for people who take risks in their teaching in order to push students. If anything, you just carry the burden of your own time of trying to do this. There's much greater reward for publishing than there is for teaching, and on and on. [Maria]

Our respondents also suggested specific knowledge and skills be developed in order to establish positive and constructive collegial relationships and most importantly, learn to relate to the community. One participant suggested that teachers unable to relate to parents could be a detriment to the education system, because, it suggests they are unable to provide support for students who are deemed at risk. The following respondent indicated that "It is incumbent on all of us to learn about the community we're servicing," and this may involve some explicit teaching and learning. To her knowledge,

Sometimes even preparing for [parent]- teacher conferences is very nervewracking for the teacher....There are some parents that attend rarely or just never seem to have time to come in and oftentimes these are the children that need the most support. These are very delicate issues and I think having an opportunity to be trained specifically in dealing with parents would be an asset for these teachers. [Joan]

Such sentiment reinforces notions that teachers, even those newly graduated, may have limited understanding of how to teach in culturally relevant ways (Ladson-Billings, 1995). Note what is not addressed in the above quote is how to tease out unintentional biases. The perception is one of training as if there is one right and correct way in which to approach parent-teacher conferences. Indeed, the suggestion of teacher training seems to allude to deeper tensions between teacher as educator and teacher as technician, echoing the disconnect some respondents described in the theory-practice rift (Barrett \& Pedretti, 2006) - a rift that has the potential of being exacerbated through assimilative mentorship practices. As one respondent noted,

We do train teachers, but, I don't think we ought to. We train them, part of it, is a treatment. Part of the training is to make them obedient - part of the training is not to have them asking questions. Part of the training is to assume that there should be some sort of a knowledge base, a checklist of teacher knowledge for being a teacher, that somehow we take this idea of being an educator and reduce it... the definition of teacher is being reduced and demeaned away from that of educator, The teacher's just really becoming this tool of the state. [Giwisay]

Many participants agreed that the teacher initiation program should address issues related to anti-oppression: social class, anti-racism, gender, anti-homophobia. Some pointed out the contrast between a student population of ethnic and social class diversity with the homogeneity of white middle-class teachers and inquired how new teachers could be initiated into understanding and relating with students from diverse class and racial or ethnic backgrounds. However, two respondents explicitly disagreed that consciousness- 
raising about social justice issues should be included in the initiation program. One participant rejected explicit inclusion of social justice issues by contending the following:

I think teachers should be developing the skills that allow them to deliver the best instruction possible. Teachers are not social workers, and I think when we try to turn teachers into social workers, we have people who are not very good social workers and not very good teachers. [Beatrice]

The suggestion is that to try and prepare teachers to do more than teach would jeopardize quality teaching. This notion, again, is in conflict with socially-just education philosophies and university mission statements that stress concern for the individual child over the teaching of an explicit set of skills and discreet knowledge base. However, while faculties of education may indicate they are teaching for social justice, this might not in fact be the case:

The system doesn't allow [for emancipator teachers]. I mean, for me, the teacher is the political worker, the social worker, is a health worker, is a cultural worker, a spiritual worker and yet what essentially happens ...they try to compartmentalize and tell us, "no," that we're a subject teacher and not only are we a subject teacher, we only teach the subject that we're going to prescribe what the subject is and then we're going to tell you how to teach that subject and then we're going to tell you to test to be able to tell if learning's taking place [Giwisay]

Such sentiment reaffirms the notion that faculties train teachers within a rigid set of constraints and, that while some teacher educators may feel the philosophy of their institution is concerned with social justice, they are rather complacent in the way it is taken up.

In terms of partnership and collaboration, a tension emerged with respect to overlooking the underlying biases and the power dynamics embedded in social institutions in favour of a discreet set of skills and the behaviours that are being emphasized in mentorship and induction programs: classroom management techniques, interactive skills with parents and community and applying a standardized curriculum.

\section{Conclusions}

Overall, teacher educators were highly supportive of a mentorship/induction model for new teachers, particularly, as an alternative to the former pen and paper test (OTQT). The varied responses from participants reinforce the notion that there are no neutral pedagogies: education is irreducibly a political and philosophical pursuit (Frere, 1998). Teacher educators see mentorship as a place for risk-taking, yet simultaneously, fear the program may be focused on conformity. Recognizing there are problematic aspects about the program's structure, some teacher educators are concerned with finding ways to disrupt the reproductive aspects of induction/mentorship programs in order to implement change within schools. The opportunity to dialogue further with experienced teachers was seen as positive, as was the potential to address on-going support and critical inquiry into practice. Other concerns pertain to the focus on the perceived "high priority needs" of new teachers which might lead to a narrow conception of what constitutes key or essential knowledge for teachers entering the profession, particularly, in an increasingly standardized teaching environment. The need to address the overwhelming pressure to conform in a climate of standardization was of paramount concern. By favoring a 
transmission model, NTIP runs the risk of socializing new teachers into established ways of knowing. New teacher induction programs that lack a critical stance will continue to reproduce and maintain the status quo and thus hinder opportunities for change.

The participants' perspectives in this study raise concerns and reservations concentrated around lack of resources, both financial and human. Most TEs believed that mentor teachers should have demonstrated mastery and excellence in teaching and have a strong critical sense. They had differing opinions in terms of where the mentors should come from: the school board, a faculty of education or the Ministry of Education. However, collaboration was seen as the key concern. The need for careful selection of mentors and the selection of the new teachers with whom they would be partnered were strongly addressed.

Tensions arose with respect to the perceived purpose of mentorship and induction. The tensions were about the positioning of the university as a research-based location versus the elementary and secondary schools constructed as practice-based locations. Several TEs are concerned with the ways in which equity content is being included or excluded in the program. In addition, tensions relating to power and control are also illuminated by respondents.

\section{Implications}

Unless systemic issues are addressed teaching for social justice may remain in the realm of theory with little translation into practice. The involvement of the Ministry and school boards without the potential critical or theoretical lens as offered by the university/faculty of education may run counter to critical democracy (DarlingHammond, 1998; Freire, 1998; Portelli \& Solomon, 2001). The study explored the idea that TEs are not homogenous by addressing them as three types of instructors: secondees, contract and permanent faculty. In this exploration we were able to derive greater detail from the respondents about their concerns with respect to the stated aims of the NTIP: balancing Ministry policies with the theoretical aspects of the university. Induction can be an opportunity to foster collegiality and increase opportunities for collaboration with the various stakeholders such as TEs, classroom teachers, administrators, parents and the community, for example. However, this requires reframing perceived hierarchies between stakeholders. The lack of direct involvement by the universities/faculties of education with mentoring and induction may further reinforce the theory-practice divide. The responsibility of mentorship should fall to a team of mentors rather than one individual at the school level.

What was clear from the teacher educators' perspective was the desire to form strong partnerships with the faculty, school boards, and possibly the Ministry of Education as well as other community stakeholders to broaden and deepen new teachers' entry into the profession and to work towards systemic change. There remains a criticism that mentoring programs are designed to reinforce the status quo, not create a model of collective, collaborative inquiry that will serve to sustain new teacher idealism and forge school cultures focused on change and socially just practices. On the one hand, an extended pre-service program, in partnership with the school boards, would facilitate both the breadth and depth deemed necessary to successful induction into teaching. However, infrastructure constraints that are coupled with the current one year or ten- 
month teacher education programs in Ontario are currently problematic. Educator workload and the context in which the program is being implemented must be taken into account. Perhaps, a new program design could be offered to include: a) a reduced work load in the first two years and b) a variety of options from which new teachers can selfselect their preferred induction process.

Embedded in the stated purpose of mentorship and induction programs is a set of assumptions that the predetermined competencies and skills new teachers should acquire are universally understood by all those involved. In order for mentorship and induction programs to focus on professional development as transformative practice rather than as technical training, programs would need to be disconnected from any form of certification. Mentoring programs that focus on outcomes as predetermined by the government and that are overly concerned with conformity and standardization could undermine teaching for democracy. The teacher educators who were interviewed suggest that a mentoring and induction program should focus on either preparing new teachers to fit into the present system, or, conversely, preparing new teachers to change the system. It is recommended that educational equity be included as part of the mentoring program context as well as part of the mentor selection criteria.

This paper adds to on-going conversations about mentorship and induction. It is abundantly clear that critical-democracy can become a reality when all stakeholders are involved in additional conversation and exploration.

\section{Acknowledgement}

This research was supported by a grant from the Social Sciences and Humanities Research Council of Canada.

While this paper is the result of a research team, the primary author for this paper is Christine Cho. We wish to thank the following who contributed in the collection of data and to general discussions of issues from this project: Nathalie Di Francesco, Fang Duan, Karen Pashby, Laura Pinto, Cindy Rottmann, Jordan Singer and Aparna Tarc.

We dedicate this paper to the memory of Dr. R. Patrick Solomon. 


\section{References}

Apple, M. (2006). Educating the "right" way: Markets, standards, God, and inequality, (2nd ed.). New York: Routledge.

Barrett, S. E., \& Pedretti, E. (2006). Contrasting orientations: STSE for social reconstruction or social reproduction? School Science and Mathematics, 106(5), $21-31$.

Bascia, N. (1996). Inside and outside: Minority immigrant teachers in Canadian schools. Qualitative Studies in Education 9(2), 151 - 165.

Bogdan, R., \& Biklen, S. (1998). Qualitative research for education: An introduction to theory and methods. Toronto: Allyn and Bacon.

Britzman, D. (1986). Cultural myths in the making of a teacher: Biography and social structure in teacher education. Harvard Educational Review, 56(4), 442-456.

Britzman, D. P. (2003). Practice makes practice: A critical study of learning to teach (Rev. ed.). Albany: State University of New York Press.

Britzman, D. P. (2007). Teacher education as uneven development: toward a psychology of uncertainty. International Journal of Leadership in Education, 10(1), 1-12.

Cho, D., \& Kwon, D. B. (2004). Determining the content of induction programs to improve instructional performance: A case in Seoul, Korea. Alberta Journal of Educational Research, 50(2), 189-199.

Cochran-Smith, M., \& Paris, P. (1995). Mentor and mentoring: Did Homer have it right? In J. Smith (Ed.), Critical discourses in teacher development (pp. 181-202). London: Cassell.

Cochran-Smith, M., \& Lytle, S. (1999). Relationships of knowledge and practice: Teacher learning in community. In the series, Review of Research in Education, 24, 249-305. Washington, DC: American Educational Research Association.

Creswell, J. W. (1998). Qualitative inquiry and research design: Choosing among five traditions. Thousand Oaks, Calif.: Sage Publications.

Darling-Hammond, L. (1998). Education for democracy. In W. C. Ayers \& J. L. Miller (Eds.), A light in dark times: Maxine Greene and the unfinished conversation (pp. 78-91). New York: Teachers College Press.

Flores, M. A. (2007). Navigating Contradictory Communities of Practice in Learning to Teach for Social Justice. Anthropology \& Education Quarterly, 38(4), 380-404. 
Foster, P. (1990). Policy and practice in multicultural and anti-racist education: A case study of a multi-ethnic comprehensive school. London: Routledge.

Freire, P. (1998). Pedagogy of freedom: Ethics, democracy and civic courage. New York: Lantham, Rowman \& Littlefield Publishers, Inc.

Giroux, H. (1983). Theory and resistance in education: A pedagogy for the opposition. Boston: Bergin \& Garvey.

Giroux, H. A. (1988). Teachers as intellectuals: Toward a critical pedagogy of learning. Granby, MA.: Bergin \& Garvey.

Hargreaves, A. (1995). Induction or seduction? Postmodern patterns of preparing to teach. Peabody Journal of Education, 70(3), 41-63.

Jones, M. (2006). The balancing act of mentoring: mediating between newcomers and communities of practice. In C. Cullingford (Ed.), Mentoring in education: An international Perspective (pp. 57-86). Hampshire, England: Ashgate Publishing Ltd.

Kennedy, V., \& Burnstein, N. (2004). Teacher induction program for special education teachers. Teacher Education and Special Education, 27(4), 444-447.

Kincheloe, J. L., \& McLaren, P. L. (1998). Rethinking critical theory and qualitative research. In N. K. Denzin \& Y. S. Lincoln (Eds.), The landscape of qualitative research: Theories and issues (pp. 260-299). London: Sage Publications.

Ladson-Billings, G (1995). Toward a theory of culturally relevant pedagogy. American Education Research Journal, 35, 465-491.

Lave, J., \& Wenger, E. (1999). Situated Learning: Legitimate Peripheral Participation. Cambridge: Cambridge University Press.

Lortie, D. C. (1975). Schoolteacher. London: University of Chicago Press.

McLaren, P. (2003). Critical Pedagogy: A look at the major concepts. In A. Darder, M. Baltodano, \& R. D. Torres (Eds.), The Critical Pedagogy Reader (pp. 69-96). New York: RoutledgeFalmer.

Ontario Ministry of Education. (2006a). New teacher induction program: Induction elements manual. Retrieved from http://tpfr.edu.gov.on.ca/NTIP/NTIPEngInductionElements-May5-Final.pdf.

Ontario Ministry of Education. (2006b). News release and backgrounder: Legislation passes to boost student performance. Retrieved June 1,2006 from http://ogov.newswire.ca/ontario/GPOE/2006/06/01/c2711.html?lmatch=\&lang=_e .html

Brock Education, 18(2) 
Portelli, J. P., \& Solomon, P. (Eds.). (2001). The erosion of democracy in education: From critique to possibilities. Calgary, Alberta: Detselig Enterprises Ltd.

Simon, R. (1992). Teachers as cultural workers. Teaching against the grain. Toronto: OISE Press.

Tashakkori, A., \& Teddlie, C. (1998). Mixed methodology: Combining qualitative and quantitative approaches. Thousand Oaks, Calif.: Sage.

Tesch, R. (1990). Qualitative research: analysis types and software tools. Bristol, PA: Falmer Press.

Villani, S. (2002). Mentoring programs for new teachers: Models of induction and support. Thousand Oaks, CA: Corwin Press.

Wang, J., \& Odell, S. J. (2002). Mentored learning to teach according to standards-based reform: A critical review. Review of Educational Research, 72(3), 481-546.

Zeichner, K., \& Gore, J. (1990). Teacher socialization. In W. R. Houston, M. Haberman, \& J. Sikula (Eds.), Handbook of research on teacher education. New York: Macmillan. 


\section{Appendix A}

\begin{tabular}{|l|l|}
\hline Question & Prompts \\
\hline $\begin{array}{l}\text { The Ministry has proposed a one-year } \\
\text { induction program with an emphasis on in- } \\
\text { school mentorship for new teachers } \\
\text { following their initial "teacher training". } \\
\text { What do you think about this proposal? }\end{array}$ & $\begin{array}{l}\text { What should an in-school mentorship } \\
\text { program look like? } \\
\text { How should it be administered? } \\
\text { What infrastructure should be put into } \\
\text { place to ensure accountability to the } \\
\text { province's broader policy mandates to } \\
\text { address equity, diversity and inclusive and } \\
\text { special education? }\end{array}$ \\
\hline $\begin{array}{l}\text { What kind of competencies should new } \\
\text { teachers be developing in order to work for } \\
\text { equity, diversity and social justice with } \\
\text { students' parents and the community? }\end{array}$ & \\
\hline $\begin{array}{l}\text { Who do you see as the most appropriate } \\
\text { mentor for new teachers and who should } \\
\text { select them? }\end{array}$ & $\begin{array}{l}\text { What criteria would you use for selection? } \\
\text { How do you think they should be prepared } \\
\text { for their job as mentors? } \\
\text { Who will provide the preparation? }\end{array}$ \\
\hline
\end{tabular}

